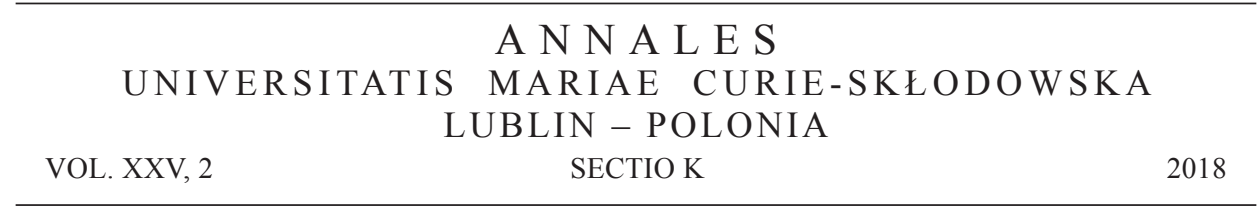

Charles University. Institute of Political Studies, Faculty of Social Sciences

\author{
DUŠAN BRABEC
}

ORCID ID: https://orcid.org/0000-0002-6604-9726

\title{
Development and Trends of the General Referendum Law Proposals in the Czech Republic
}

\begin{abstract}
The possibilities of introducing elements of direct democracy into the Czech constitutional framework are often being reduced to efforts to implement a general referendum. During more than 25 years of the existence of the independent Czech Republic, the Czech parliament discussed 21 proposals of the general referendum law. However, despite the relatively large number of the proposals, the Czech legislators did not agree on the form which the general referendum should have in the Czech Republic - none of the submitted proposals of the law on the general referendum has so far been accepted. Proposals of the general referendum law were not identical. Therefore, this paper aims to analyse 21 proposals submitted to the Czech parliament. The main emphasis will be put on the overall role which a general referendum should fulfil in case it is implemented into the Czech legal framework. Should a general referendum serve only as a complementary instrument in the context of parliamentary democracy applied in the Czech Republic or should it be used as a regular tool to exercise power by citizens of the Czech Republic which corresponds much more to the system based on direct democracy? Which of these poles are the proposals approaching, or is it possible to observe a certain trend in the submitted proposals of the general referendum laws? Are the proposals, that are repeatedly submitted by the same political parties, consistent in their content? Those are the main issues, which will be addressed in this paper.
\end{abstract}

Key words: referendum, the Czech Republic, proposal

\section{INTRODUCTION}

The necessity to introduce mechanisms of direct democracy (especially the general referendum) into the Czech legal framework has been strongly articulated already for some time in the Czech Republic. This is also emphasised by the fact that three 
different political parties (namely SPD - Freedom and Direct Democracy, KSČM Communist Party of Bohemia and Moravia, and ČSSD - Czech Social Democratic Party) have been submitting a general referendum law proposals since the formation of the Chamber of Deputies in October 2017. Since the establishment of the independent Czech Republic in 1993, the Chamber of Deputies has already discussed 21 draft laws on general referendum. The main aim of this thesis is to assess to what extent the presented proposals of the general referendum law differ, and whether we can observe a general trend in the proposals submitted by the political parties over the past 25 years.

The article is divided into several sections. The first part will briefly introduce the constitutional framework of the Czech Republic in the context of a general referendum and other instruments of direct democracy that are used in the Czech Republic. Consequently, the second part will be devoted to the theoretical background, conceptualisation and method of analysis of the examined general referendum law proposals. In the third section, the method chosen for the analysis of the concerned proposals will be applied to the empirical data. Last but not least, the final part of the thesis will draw specific conclusions from the analysis of the examined proposals of the general referendum law submitted in the last 25 years.

\section{CONSTITUTIONAL BACKGROUND FOR A GENERAL REFERENDUM}

The introduction of elements of direct democracy (especially the general referendum) into the Czech legal framework has been part of the Czech political debate since the establishment of an independent Czech Republic [Pechanec 2011: 1]. This long-lasting political debate is based on the fact that in Article 2, the Czech Constitution [1992] states: "constitutional act may define when people exercise state power directly". Therefore, the Czech Constitution treats the general referendum as a possible but not necessary complement to a representative democracy that is applied in the Czech environment [cf. Pechanec 2011: 40; Sládeček, Mikule, Syllová 2007: 18]. The Czech Constitution assumes that the introduction of a general referendum into the Czech legal framework should be based on the implementation of the constitutional law on general referendum [Pechanec 2011: 40; Pavlíček 2002: 56]. ${ }^{1}$ This corresponds to the fact that a constitutional amendment was introduced in 2001, based on which the Czech parliament allowed ratification of an international treaty in a referendum [Pechanec 2011: 42; Kużelewska 2014: 100]. This amendment allowed the introduction of a Constitutional Act on the Referendum on the Accession of the Czech Republic to the European Union [2002]. Based on this, a first and last nationwide referendum in the history of the independent Czech Republic was held.

1 Other authors have the opposite view that the implementation of a general referendum can also occur on the basis of the adoption of the ordinary law. For comparison: Pavlíček, Hřebejk [1998: 60]; Mates [2004: 14]. 
However, another approach was applied by Czech legislators regarding the implementation of local and regional referendums when both direct democracy mechanisms were introduced under ordinary law. Local referendums were lawfully amended in 2004; regional referendums were then implemented in 2011 [Pechanec 2011: 45]. ${ }^{2}$

\section{THE CURRENT STATE OF DIRECT DEMOCRACY IN THE CZECH REPUBLIC}

Although the general referendum is not part of the Czech legal framework, the predecessors of today's Czech Republic (specifically, Czechoslovakia in inter-war period and the Czechoslovak Federal Republic) had specific adjustments of this mechanism implemented in their constitutions [Lebeda 2003: 207-208]. However, it is also important to emphasize that even though the referendum was part of the Constitution of the Czechoslovak Republic and the Czechoslovak Socialist Republic, it has never been used in practice.

As it was mentioned above, there has only been one referendum at the national level - a referendum on the Czech Republic's accession to the European Union. ${ }^{3}$ In contrast to the general referendums, local referendums are relatively popular [Špok et al. 2006: 19-30]. Only between 2006 and 2018, 270 local referendums took place in the Czech Republic [Local referendums report table 2018]. When it comes to a regional referendum, none has been held in the Czech Republic so far. Among the mechanisms of direct democracy that are not implemented in the Czech legal framework is the socalled participatory budgeting. The participatory budgeting was first used in the Czech Republic in 2014 [Vojtíšková 2016] and its popularity has been constantly on the rise. However, the largest legal challenge in the context of the use of direct democracy in the Czech Republic is the implementation of a general referendum law.

\section{THEORETICAL BACKGROUND}

Since the establishment of the independent Czech Republic, the Parliament of the Czech Republic has received 21 draft laws on the general referendum. From the beginning (in the 1990s), the general referendum was considered primarily as a complementary instrument serving only in exceptional situations within the parliamentary regime. However, over time, referendums have begun to be considered as a common mechanism by which citizens of the Czech Republic have been involved in the Czech governance (this is particularly evident in the proposals submitted in the recent years).

\footnotetext{
2 The way of introducing these mechanisms of direct democracy has become the subject of several academic polemics [cf. Pechanec 2011: 45; Mates 2007: 55; Vedral 2004: 13].

3 More than $55 \%$ of the eligible voters participated in this referendum, $77.33 \%$ of them supported the accessing of the Czech Republic to the EU [Perottino 2005: 28-29].
} 
Therefore, we can infer that the relationship of legislators to the form of a general referendum has changed over time (at least in relation to the content of the proposed draft of the general referendum law). ${ }^{4}$ The main puzzle is to calculate or evaluate if a general trend as described above is or is not present in the draft proposals. Nevertheless, when measuring the potential of direct democracy, we can run into several problems: "Typologies, scales, and even indices of direct democracy are relatively new in the discipline. Most of these endeavors face one or more of six major flaws, to differing degrees" [Altman 2017: 1211]. As David Altman [2017] states, the most common shortcomings of these indexes or typologies is their scope, which often only covers a few specific (often very similar) cases. ${ }^{5}$ Moreover, some of the typologies work with the concept of direct democracy too vaguely, or they are not able to sufficiently distinguish between specific mechanisms of direct democracy in specific cases and given contexts [Altman 2017: 1211]. Therefore, Altman offers his own way of measuring the potential of direct democracy in the studied countries. These measurements are based on his index - Direct Democracy Practice Potential. "This index results from the aggregation of the scores of four types of mechanisms of direct democracy: popular referendums, referendums, mandatory referendums, and authorities' plebiscites" [Altman 2017: 1207]. Using this index, we can measure: a) how easy it is to initiate and approve each type of popular vote, and b) how consequential that vote is if approved [Altman 2017: 1207]. ${ }^{6}$

The Altman index offers a new and interesting approach of evaluating the levels of direct democracy in a particular country in a given time period. This index was created especially for the purpose of comparing specific countries in the context of the use of direct democracy mechanisms implemented by the countries themselves. However, for the purposes of this work, this index (at least in its basic form) would not be suitable. The purpose of this article is not to examine the extent to which direct democracy is developed in the Czech Republic (possibly to compare this level with other countries), but to assess whether a certain trend in the submitted proposals for the law on general referendum can be observed. For this purpose, the Altman index would need to be significantly modified. ${ }^{7}$ However, this will not be necessary due to the nature of the

${ }^{4}$ It is obvious that Czech legislators are relatively skeptical about the possibility of implementing the general referendum into the Czech legal framework. Cf. Šimíček [2003: 141].

5 For illustration, let us mention a few cases dealing with Western European countries. For example, Gross and Kaufmann's [2002] study applied its own European country index on citizen law making in 32 European countries or Vatter's [2009] study which dealt with 23 OECD member countries.

6 Those components are then aggregated via variables: a) ease of initiation: 1) existence of direct democracy process, 2) number of signatures needed, 3) time-limits to circulate the signatures; b) ease of approval: 1) participation, 2) approval, 3) supermajority, 4) district majority; c) vote's consequentiality: 1) legal status of decision made (binding, consultative), 2) threat capability [Altman 2017: 1216-1217].

7 If we apply this index to a general referendum in the Czech Republic, we would get score $=0$, i.e. general referendum is not implemented into the Czech legal framework. To assess the power of the referendums on the basis of their proposals, it would be necessary to modify the calculation of the index formula. Respectively leave only the suitable variables: a) ease of initiation: 1) number of sigantures needed, 2) time-limits to circulate the signatures; b) ease of approval: 1) participation, 2) approval, 3) supermajority; c) vote's consequentiality: 1) legal status of decision made (binding, consultative). 
data being considered. The analyzed documents are drafts of the general referendum law submitted to the Chamber of Deputies of the Czech Republic in the last 25 years. Although they differ in their form as well as the factual content, the key variables that will be analyzed in this paper are included in all the examined documents. The main research hypotheses of this paper are as follows: a) Over time, it can be observed that the role of the drafts of the law on the general referendum has shifted from their original role as a complementary tool to common mechanisms of directly exercised power by the citizens; b) The parliamentary parties that have initiated the general referendum law several times have been consistent in the content of such proposals.

\section{ANALYZED COMPONENTS}

Because general referendum law proposals are quite different both in their form and content, we will analyze three key independent variables.

1. Initiation Threshold

2. Restrictions

3. Approval Quorum

The dependent variable would be the fact whether the referendum as presented in the law proposals corresponds rather to the complementary instrument of the parliamentary regime or vice versa to the mechanism of direct exercise of the power by the citizen of the Czech Republic.

The aim of this analysis will be to find out to what extent we can empirically prove that in the 25 years of the existence of the independent Czech Republic, general referendum law proposals changed in their content and more specifically in the role that the instrument should fulfil. The individual referendum law proposals or rather the above-mentioned three key variables (which are common to all the proposals examined) will be analyzed with regard to whether their values are more likely to be related to a referendum in the sense of representative democracy or direct democracy. The values that the specific variables will acquire will not be related to the absolute scale - the specific values will not directly express how much is the referendum law proposal approaching one or the other pole (direct democracy or representative democracy). On the contrary, in order to get their ranking, the variables will be related to one another - a general referendum law proposal from a selected sample of proposals examined which is closest to the concept of a complementary mechanism within representative democracy will have the highest possible value (i.e. it will be the most restrictive in relation to the variables analyzed), whereas the referendum which is closest to the role it should fulfill within the framework of direct democracy will reach the lowest values (such a referendum law proposal will be the least restrictive with respect to the analyzed variables). Since we will compare the drafts of the general referendum law only amongst each other, the highest achievable value (score) may be 21 (this corresponds to the total number of proposals examined), the lowest score may be 1 . 
The result of the analysis will be a chart (or a group of graphs) that will represent the relative (not absolute) relationship between the general referendum law proposals and their position towards the $\mathrm{Y}$ axis - a referendum within the system of representative democracy (a complementary instrument) - a referendum as part of direct democracy system (direct exercise of power by citizens); at a given time - the $\mathrm{X}$ axis. In other words, the analysis will serve to classify drafts of general referendum law according to their restrictiveness (or strictness of the independent variables examined). The aim of the thesis is not to present a general index for measuring the power of general referendums (general referendum laws). However, for the purposes of the analysis, a formula will be presented in the text. Each of the analyzed general referendum law proposals was evaluated based on this formula. When analyzing the data set, the emphasis will be put on conceptualization, measurement and subsequent aggregation of data, as Gerardo Munck and Jay Verkuilen [2002] stress.

\section{EMPIRICAL PART.}

\section{CONCEPTUALIZATION OF VARIABLES AND THEIR MEASUREMENT}

As mentioned above, the analysis will be based on three key variables. The first one, the so-called Initiation Threshold, expresses the number of citizens' signatures that needs to be collected under the petition for the general referendum to be initiated (according to a specific draft of the general referendum law).

Table 1. General referendum law proposals

\begin{tabular}{|c|c|c|c|}
\hline $\begin{array}{l}\text { Parliamentary } \\
\text { term }\end{array}$ & Political party & $\begin{array}{c}\text { Year of } \\
\text { proposal }\end{array}$ & $\begin{array}{c}\text { Number of citizens' signatures needed for the referendum to } \\
\text { be initiated }\end{array}$ \\
\hline \multirow{3}{*}{ 1993-1996 } & HSD-SMS (No. 494) & 1993 & $\begin{array}{l}10 \% \text { of citizens ( } 15 \% \text { when initiating a referendum on the } \\
\text { specific law) }\end{array}$ \\
\hline & ČSSD (No. 1874) & 1995 & Citizens can't initiate \\
\hline & KSČM (No. 2096) & 1996 & 250,000 \\
\hline \multirow{2}{*}{ 1996-1998 } & KSČM (No. 104) & 1996 & 250,000 \\
\hline & ČSSD (No. 149) & 1997 & Citizens can't initiate \\
\hline \multirow{4}{*}{ 1998-2002 } & ČSSD (No. 18) & 1998 & Citizens can’t initiate \\
\hline & KDU-ČSL (No. 120) & 1999 & 250,000 \\
\hline & ČSSD (No. 695) & 2000 & 500,000 \\
\hline & ČSSD (No. 1039) & 2001 & 300,000 (later edited to 500,000 ) \\
\hline $2002-2006$ & ČSSD (No. 914) & 2005 & 500,000 (later edited to 300,000 ) \\
\hline \multirow{2}{*}{$2006-2010$} & KSČM (No. 134) & 2007 & 200,000 \\
\hline & ČSSD (No. 192) & 2007 & 200,000 \\
\hline \multirow{3}{*}{ 2010-2013 } & ČSSD (No. 8) & 2010 & 200,000 \\
\hline & ČSSD (No. 520) & 2011 & 200,000 \\
\hline & LIDEM (No. 661) & 2012 & 250,000 \\
\hline
\end{tabular}




\begin{tabular}{|c|c|c|c|}
\hline $\begin{array}{c}\text { Parliamentary } \\
\text { term }\end{array}$ & Political party & $\begin{array}{l}\text { Year of } \\
\text { proposal }\end{array}$ & $\begin{array}{c}\text { Number of citizens' signatures needed for the referendum to } \\
\text { be initiated }\end{array}$ \\
\hline \multirow{3}{*}{ 2013-2017 } & Úsvit (No. 114) & 2014 & 100,000 \\
\hline & KSČM (No.116) & 2014 & 100,000 \\
\hline & ČSSD (No. 559) & 2015 & 250,000 \\
\hline \multirow{3}{*}{$2017-$} & SPD (No. 35) & 2017 & 100,000 \\
\hline & ČSSD (No. 111) & 2018 & 850,000 \\
\hline & KSČM (No. 117) & 2018 & 100,000 \\
\hline
\end{tabular}

Source: Author's own studies based on data provided by Czech and Slovak Digital Parliamentary Library.

As can be seen in Table 1, general referendum law proposals that were submitted by $\breve{C S S D}$ in the 1990 s would not allow citizens to initiate a general referendum. ${ }^{8}$ The other proponents of this law then proposed a limit of 250,000 signatures (except the first draft submitted by HSD-SMS [No. 494, 1993]) for the general referendum to be called out. Between 1998 and 2006, when Social Democracy was the strongest party of the governing coalition, it submitted drafts of the general referendum law where the thresholds for the number of signatures needed to initiate a referendum were very different. In 1998, ČSSD proposed a law that would not allow citizens to initiate a general referendum [No. 18]. In 2005, which was already the sixth draft of the general referendum law [No. 914] submitted by ČSD, the draft has set the threshold for 300,000 signatures. ${ }^{9}$ After the departure of C SSD into opposition, its drafts of the general referendum law (specifically from 2007 [No. 192], 2010 [No. 8] and 2011 [No. 520]) were consistent regarding the number of signatures that had to be collected to initiate a general referendum. However, a relatively large turn in the strategy of CSSD (at least with regard to the proposed drafts of the general referendum law) was evident after the emergence of populist parties after 2013 (Úsvit and SPD). As can be seen from the submitted proposals (2015 [No. 559] and 2018 [No. 111]), ČSSD attempted to propose an alternative to the drafts of the general referendum law submitted by the populist parties. General referendum law proposals of the populist parties introduced the historically lowest threshold in terms of the signatures that needed to be collected in order to call out a general referendum (i.e. only 100,000 signatures). ${ }^{10}$

The table also indicates that the second most frequent proponent of the general referendum law - KSČM (5 proposals in the analyzedtime period) - has always included in its proposals the possibility to initiate a general referendum by the citizens. In the 1990s, the threshold was the highest (250,000 signatures [No. 2096, 1996; No. 104, 1996]) and in 2018 [No. 117], the Communists proposed a limit of only 100,000 citizens' signatures.

8 Specifically, there were three drafts of the general referendum law - No. 1874 [1995], No. 149 [1997], No. 18 [1998].

9 More precisely, this threshold was established on the basis of the adopted amendment [No. 914/2, 2005].

${ }_{10}$ The first of these proposals was presented by Úsvit in 2014 [No. 114], the second proposal was submitted in 2017 [No. 35] by the indirect successor of Úsvit - SPD. 
The second key variable that will be analyzed is the so-called Restrictions, i.e. questions (or topics) that the general referendum could not be about (according to the submitted drafts of the general referendum law). In the more detailed analysis of the individual proposals, it is clear that the drafts of the general referendum law presented in the 1990s (namely 3 proposals - one HSD-SMS [No. 494, 1993], the remaining two KSČM [No. 2096, 1996; No. 104, 1996]) considered the general referendum only in a pre-given questions. ${ }^{11}$ These drafts, therefore, included a socalled positive definition of the subject on which the referendum could be called out (a general referendum could not be held for other than the defined areas). Other drafts of the general referendum law defined the subject of the referendum negatively (that is, the referendum could be held on all issues that are not prohibited by the law). The most frequent topics that could not be voted about in the general referendum included: changes in the essential parts of democratic state according to the rule of law; fundamental human rights; adjustments that would be contrary to the international treaties and obligations of the Czech Republic; court decisions or public expenditure and revenue (tax burden issues). The least restrictions were included in the proposals submitted by populist parties - namely LIDEM [No. 661, 2012], Úsvit [No. 114, 2014] and SPD [No. 35, 2017]. ${ }^{12}$

The third key variable is the so-called Approval Quorum. That is the number of votes required for the adoption of the proposal on which the referendum was held. The summary of the Approval Quorum for the individual general referendum law proposals is provided in Table 2 .

Table 2. General referendum law proposals

\begin{tabular}{|c|c|c|c|c|}
\hline Parliamentary term & Political party & Year & Approval quorum & Participation quorum \\
\hline \multirow{3}{*}{ 1993-1996 } & HSD-SMS (No. 494) & 1993 & $<50 \%$ of eligible voters ${ }^{13}$ & none \\
\hline & ČSSD (No. 1874) & 1995 & $<50 \%$ of eligible voters & none \\
\hline & KSČM (No. 2096) & 1996 & $<50 \%$ of eligible voters & none \\
\hline \multirow{2}{*}{ 1996-1998 } & KSČM (No. 104) & 1996 & $<50 \%$ of eligible voters & none \\
\hline & ČSSD (No. 149) & 1997 & none & $<33 \%$ of eligible voters \\
\hline \multirow{4}{*}{ 1998-2002 } & ČSSD (No. 18) & 1998 & none & $<33 \%$ of eligible voters \\
\hline & KDU-ČSL (No. 120) & 1999 & none & $<33 \%$ of eligible voters \\
\hline & ČSSD (No. 695) & 2000 & $<50 \%$ of eligible voters & none \\
\hline & ČSSD (No. 1039) & 2001 & none & none \\
\hline $2002-2006$ & ČSSD (No. 914) & 2005 & none & none \\
\hline
\end{tabular}

${ }^{11}$ In particular, the issues of sovereignty, territorial integrity and territorial organization of the Czech Republic were included in the drafts submitted by KSČM [No. 2096, 1996; No. 104, 1996]. HSD-SMS then advocated the adoption of a general referendum law which could only take place in matters of domestic or foreign policy of the state, and issues of acceptance or repeal of the law [No. 494, 1993].

12 Proposals of the general referendum law submitted by Úsvit [No. 114] and SPD [No. 35] would, in case a referendum was initiated, allow citizens to decide on issues of state revenues and expenditures.

${ }^{13}$ The proposal submitted by HSD-SMS required a threshold of $<50 \%$ of eligible voters, but it also introduced a possible alternative of $<50 \%$ of involved voters [No. 494, 1993]. 


\begin{tabular}{|c|c|c|c|c|}
\hline Parliamentary term & Political party & Year & Approval quorum & Participation quorum \\
\hline \multirow[b]{2}{*}{ 2006-2010 } & KSČM (No. 134) & 2007 & none & none \\
\hline & ČSSD (No. 192) & 2007 & $\begin{array}{l}<33 \% \text { of eligible voters } \\
\bullet \text { needs to represent at } \\
\text { least }<50 \% \text { of involved } \\
\text { voters }\end{array}$ & none \\
\hline \multirow{3}{*}{ 2010-2013 } & ČSSD (No. 8) & 2010 & $\begin{array}{l}<33 \% \text { of eligible voters } \\
- \text { needs to represent at } \\
\text { least }<50 \% \text { of involved } \\
\text { voters }\end{array}$ & none \\
\hline & ČSSD (No. 520) & 2011 & $\begin{array}{l}<33 \% \text { of eligible voters } \\
\bullet \text { needs to represent at } \\
\text { least }<50 \% \text { of involved } \\
\text { voters }\end{array}$ & none \\
\hline & LIDEM (No. 661) & 2012 & none & $<50 \%$ of eligible voters \\
\hline \multirow[b]{3}{*}{ 2013-2017 } & \begin{tabular}{|l|} 
Úsvit (No. 114) \\
\end{tabular} & 2014 & none & none \\
\hline & KSČM (No.116) & 2014 & none & none \\
\hline & ČSSD (No. 559) & 2015 & $\begin{array}{l}<25 \% \text { of eligible voters } \\
\bullet \text { needs to represent at } \\
\text { least }<50 \% \text { of involved } \\
\text { voters }\end{array}$ & none \\
\hline \multirow{3}{*}{$2017-$} & SPD (No. 35) & 2017 & none & none \\
\hline & ČSSD (No. 111) & 2018 & $<50 \%$ of eligible voters & none \\
\hline & KSČM (No. 117) & 2018 & none & none \\
\hline
\end{tabular}

Source: Author's own studies based on data provided by Czech and Slovak Digital Parliamentary Library.

It is evident that the law proposals on general referendum submitted in the 1990s required the majority of votes of the eligible voters so that the subject of the referendum could be approved. ${ }^{14}$ Gradually, the conditions under which a referendum would be approved were less strict - the overall majority of the votes was sufficient, but at least $1 / 3$ of the eligible voters had to vote. That means that the approval quorum was broadened by the so-called participation quorum. Since 2001, however, all law proposals (except the proposals submitted by social democrats after 2006 and the proposals submitted by LIDEM in 2012 [No. 661] $)^{15}$ did not set any approval quorum - that means that the subject of a referendum would be approved if a majority of the voters that voted in the referendum approved its subject. On the other hand, the law proposal on general referendum submitted by ČSSD since 2007 demonstrates that in the context of the approval quorum, the threshold for a referendum to be approved has become more strict. ${ }^{16}$

${ }^{14}$ This supports the statement that: "quorums are a simple way of protecting the status quo" [Maniquet, Morelli 2010: 2].

${ }^{15}$ LIDEM in its proposal [No. 661, 2012] required an absolute majority of the voters' votes cast for the referendum. The number also had to represent at least one third of all eligible voters.

${ }^{16}$ Between 2007 and 2011, ČSSD submitted three proposals - No. 192, 2007; No. 8, 2010; No. 520, 2011 - according to which at least one third of all eligible voters of the Czech Republic had to accept the subject of the referendum. For the adoption of the subject of the referendum, at least one-half of the involved voters had to support the matter. In the proposal of the Social Democrats in 2015 [No. 559], this 


\section{DATA AGGREGATION}

For the overall breakdown of the analyzed drafts of the general referendums law, it is necessary to introduce the aggregated scores $\left(\mathrm{AG}_{\mathrm{SC}}\right)$ of the key variables. The individual values of $\mathrm{AG}_{\mathrm{SC}}$ (for each proposal) will correspond to the rank of the submitted proposal. All key variables or their scores have the same weight.

For a better illustration - the lowest partial score within the Initiation Threshold $\left(\mathrm{IT}_{\mathrm{SC}}\right.$ ), i.e. score $=1$, will receive four analyzed proposals - two proposals submitted by KSČM first in 2014 [No. 116] and second in 2018 [No. 117], the proposal submitted by Úsvit in 2014 [No. 114] and the proposal submitted by SPD in 2017 [No. 35]. The highest score will then be given to the draft of the general referendum law that would not allow citizens to initiate a referendum (score $=8$ ), that would be namely three proposals submitted by ČSSD in 1995 [No. 1874], 1997 [No. 149], and 1998 [No. 18].

In the context of the second key variable - Restrictions $\left(\mathrm{R}_{\mathrm{SC}}\right)$, the score will be assigned to each of the analyzed proposals accordingly. The highest scores will be given to those proposals that are most restrictive in the sense of invoking the referendum. The lowest score will then receive those proposals that allow a general referendum to take place in the widest possible range of issues.

The lowest score for the third key variable, the Approval Quorum $\left(\mathrm{AQ}_{\mathrm{SC}}\right)$, will receive those proposals that required the lowest threshold for the subject to be approved in a referendum. The highest scores will be assigned to the proposals that required the highest threshold for the acceptance of the referendum.

The following formula will be used to calculate the aggregated scores:

$\mathrm{AG}_{\mathrm{SCx}}=\left(\mathrm{IT}_{\mathrm{SCx}}+\mathrm{R}_{\mathrm{SCx}}+\mathrm{AQ}_{\mathrm{SC}}\right) / 3$

The following graph represents aggregated scores $\left(\mathrm{AG}_{\mathrm{SC}}\right)$ of all of the analyzed general referendum law proposals.

At first glance, it is clear that the drafts of the general referendum law in the context of the analyzed key variables have undergone major changes over the last 25 years. In the $1990 \mathrm{~s}$, a general referendum was considered as a mechanism that should be used in unique circumstances (which, moreover, corresponds to the values of key variables). On the other hand, the proposals submitted by populist parties in the last few years (law proposals submitted by Úsvit in 2014 [No. 114] and the law proposal submitted by SPD in 2017 [No. 35]), wanted to implement a general referendum that should serve as a commonly used mechanism.

When analyzing drafts of the general referendum law, a general trend can be traced. As the time passed by, more liberal (in certain cases permissive) drafts of the general referendum law were submitted. An exception to this were drafts submit-

condition was reduced to one-fourth of all eligible voters and with more than $50 \%$ of those who came to the referendum. In 2018 [No. 111], ČSSD demanded that more than $50 \%$ of all eligible voters of the Czech Republic have to support the subject of a referendum. 


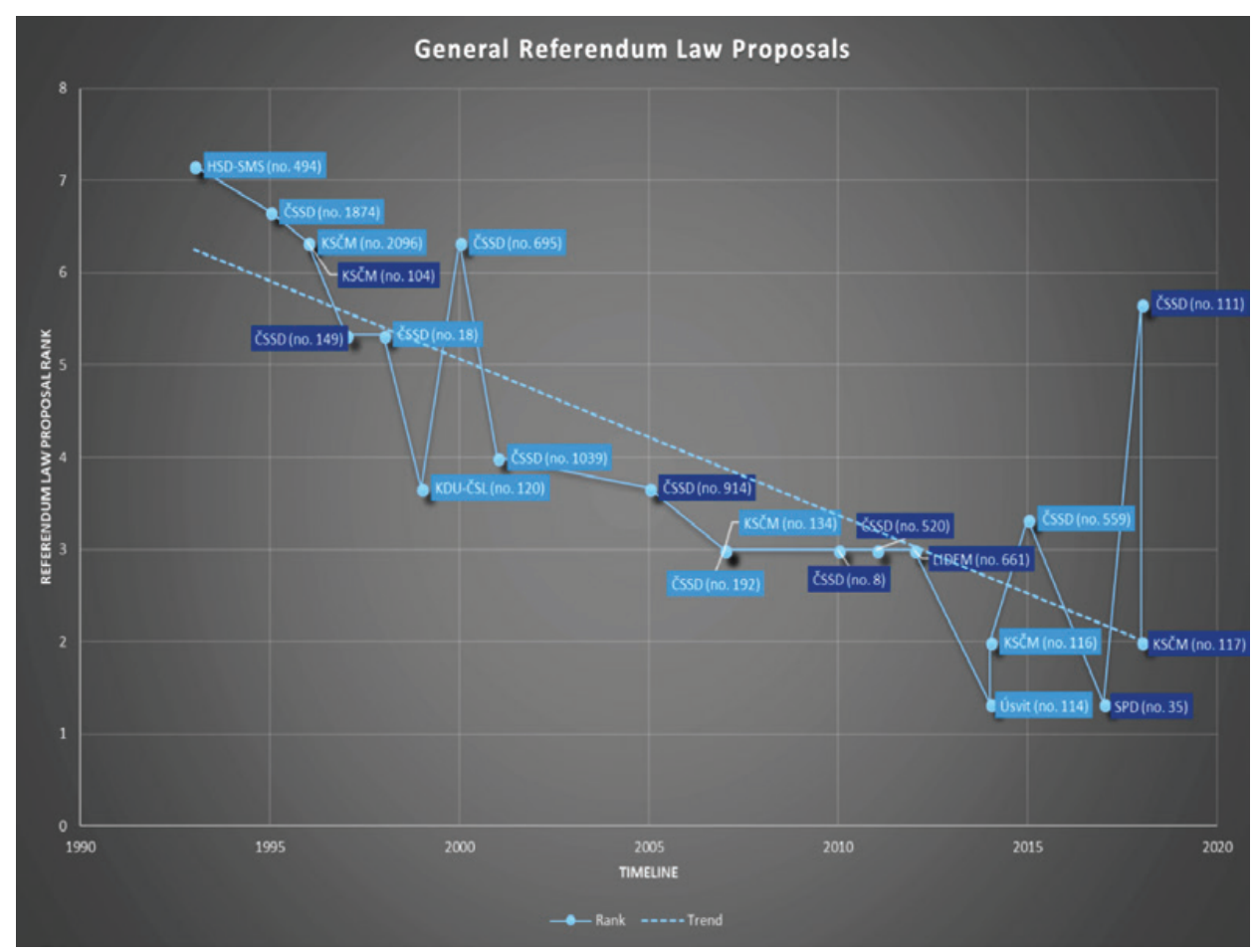

Figure 1. General Referendum Law Proposals, based on Table 3

Source: Author's own study.

ted by the Social Democrats in 2015 [No. 559] and 2018 [No. 111]. Those general referendum law proposals were more restrictive than other drafts submitted in the sametime period.

Considering the consistency of the general referendum laws proposed by ČSSD, it should be noted that ČSSD submitted lots of very different proposals in the last 25 years. Whereas between 1995 and 2011, ČSSD submitted drafts of the general referendum law which corresponded to the general trend described above - that the proposals presented in the 1990s were the most strict in the context of the analyzed variables compared to the proposals submitted later. The most "liberal" proposals were submitted by ČSSD to the Chamber of Deputies in 2007 [No. 192], 2010 [No. 8 ] and 2011 [No. 520]. The two most recent proposals that were trying to implement general referendum (2015 [No. 559] and 2018 [No. 111]) were once again more restrictive. These proposals were submitted by ČSSD in response to the attempts of the populist parties (Úsvit in 2014 [No. 114] and SPD in 2017 [No. 35]) to implement a permissive general referendum.

KSČM - a party that has submitted the second highest number of the general referendum law proposals ( 5 in total) - has chosen a different strategy when submitting these law proposals. KSČM has been relatively consistent, at least regarding the content of the proposals they have submitted. These proposals correspond to the general trend 


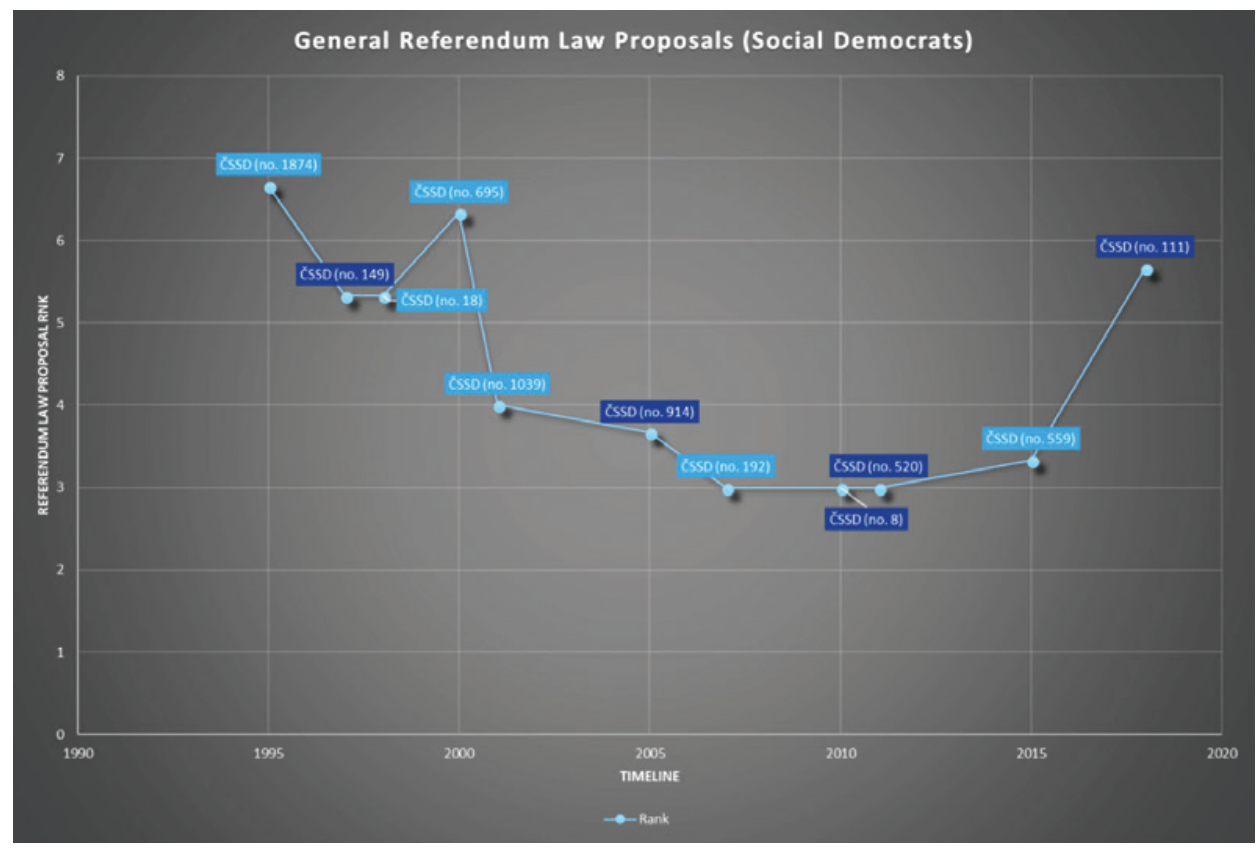

Figure 2. General Referendum Law Proposals (Social Dmocrats), based on Table 3

Source: Author's own study.

of "softening" the conditions under which the general referendum could be potentially initiated and accepted. An interesting fact is that in case a general referendum law proposed by KSČM was rejected, Communists have often tried to implement the almost identical copy of the same proposal in the next parliamentary term. This strategy was chosen by KSČM already twice. In particular, the 1996 proposal [No. 2096] was almost a literal copy of the Communist proposal submitted earlier in 1996 [No. 104]. The same thing happened in 2018 with the submitted proposal [No. 117], which copied to a large extent the previous Communist proposal submitted in 2014 [No. 116]. Also, even though the Communist general referendum law submitted in 2007 [No. 134] was not a copy of the previous Communist proposal, it, to a large extent, coincided with the governmental proposal of a similar law submitted by ČSSD in 2005 [No. 914]. ${ }^{17}$

However, even ČSSD, as the most frequent proponent of the general referendum law, has submitted the same proposal repeatedly. This applied in particular to the drafts of the laws submitted in 2010 [No. 8] and 2011 [No. 520], which almost literally copied the general referendum law submitted by ČSSD in 2007 [No. 192]. ${ }^{18}$

${ }^{17}$ However, the Communist draft of the law submitted in 2007 differed from the government's proposal [2005] in terms of the general referendum initiation conditions [No. 134, 2017].

${ }_{18}$ In 1998, ČSSD submitted a draft of the law, which except the articles implementing the People's Initiative, almost literally copied the draft of the previous law submitted by ČSSD in 1997 [No. 18, 1998; No. 149, 1997]. 


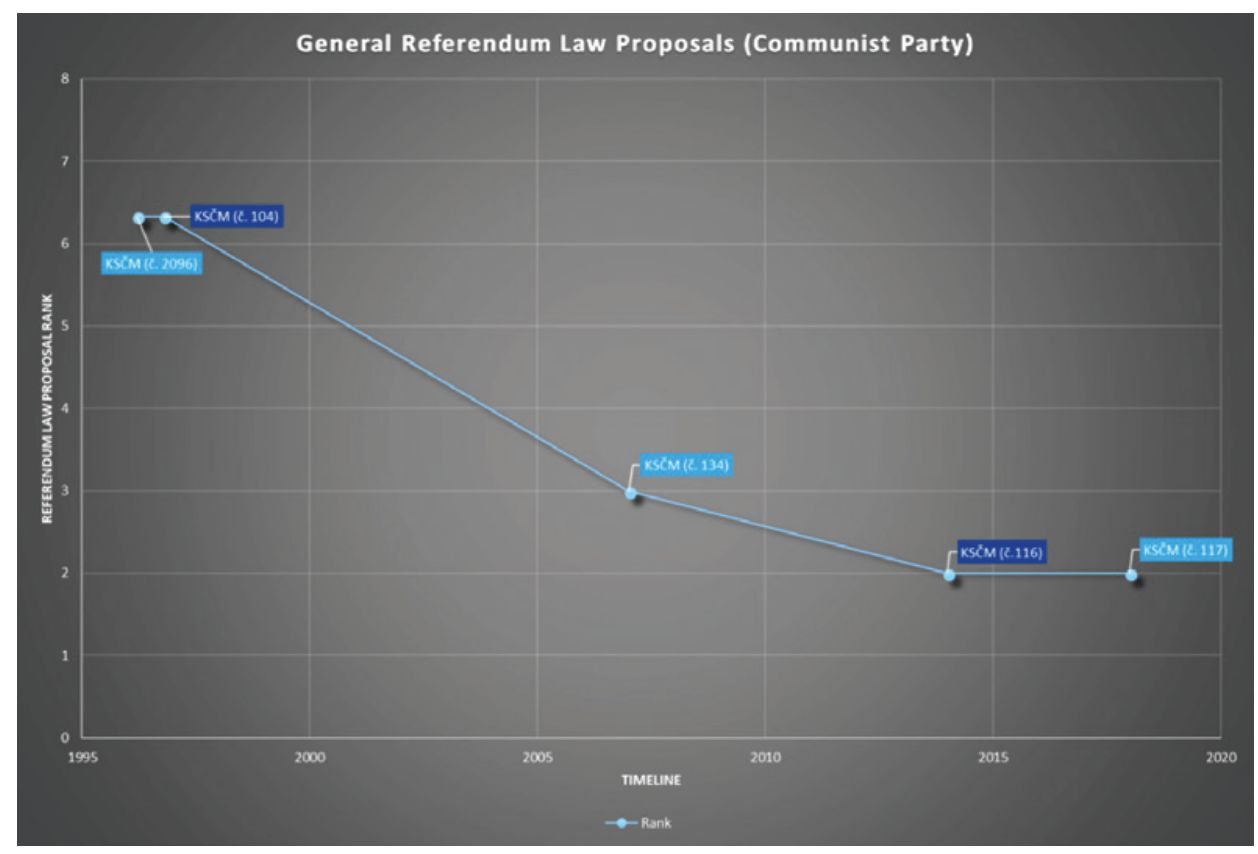

Figure 3. General Referendum Law Proposals (Communist Party), based on Table 3

Source: Author's own study.

\section{CONCLUSIONS}

Czech politicians have been discussing the implementation of direct democracy instruments, especially the general referendum, over the last quarter of a century. In spite of the relatively large number ofgeneral referendum law proposals submitted by different political parties (21 in total), Czech legislators did not accept any of them. After analyzing the individual drafts of the general referendum law, it can be concluded that these documents vary considerably regarding their content and the role that the general referendum should fulfil.

While in the 1990s the general referendum was considered to be a complementary instrument that citizens could use under very exceptional circumstances, proposals that were submitted in recent years tried to implement general referendum as a mechanism that the citizens could use relatively often without any significant restrictions. In the 1990s, the referendum was designed as a complementary mechanism within the framework of representative democracy practiced in the Czech Republic. In recent years, there have been opinions advocating wider use of elements of direct democracy. This rhetoric was very often used by the new populist parties (Úsvit, SPD) who have tried to implement a very permissive general referendum. Such a referendum could be a major threat to a representative democracy that has been practiced in the Czech Republic in the last 25 years. 
While SPD submitted an almost identical proposal as its indirect predecessor - Úsvit (the least restrictive proposals of the law on the general referendum), the most frequent proponent of the general referendum law - ČSSD, often changed the form of the general referendum proposals submitted by them. While before 2013, the Czech Social Democracy followed a general trend with more liberal proposals of a general referendum law over time. After 2013 and the entry of populist parties into the Czech Parliament, ČSSD submitted much more strict drafts of the general referendum law, as an alternative to the very permissive proposals submitted by Úsvit and SPD.

Also, KSČM as the second most frequent proponent of the general referendum law, wanted to implement a general referendum five times during the last 25 years. KSČM followed a general trend when it presented proposals that were trying to implement relatively strict general referendum in the 1990s. Over time, they submitted proposals that were much more liberal. However, KSČM has submitted several proposals to the Chamber of Deputies that were almost identical copies of the previous drafts of the general referendum law. This strategy was chosen by KSČM for three of the five submitted proposals. A similar strategy was used by CSSD for three proposals submitted between 2007 and 2011 (however, the ratio of the "copied" drafts to the original drafts of the general referendum law when talking about CSSD is significantly lower - only 3 of 11 submitted proposals were copies).

Although it is quite interesting to see the political debate on how the general referendum should look like and what role it should fulfil, the main question still remains: When, and in what form will a general referendum (or other direct democracy mechanism) be implemented in the Czech Republic at the national level?

\section{APPENDIX}

Table 3. Aggregated scores for analyzed variables

\begin{tabular}{|c|c|c|c|c|c|c|}
\hline $\begin{array}{c}\text { Parliamentary } \\
\text { term }\end{array}$ & Political party & Year & $\mathrm{IT}_{\mathrm{SC}}$ & $\mathrm{R}_{\mathrm{SC}}$ & $\mathrm{AQ}_{\mathrm{SC}}$ & $\mathrm{AG}_{\mathrm{SC}}$ \\
\hline \multirow{3}{*}{ 1993-1996 } & HSD-SMS (No. 494) & 1993 & 7 & 8 & 6.5 & 7.2 \\
\hline & ČSSD (No. 1874) & 1995 & 8 & 5 & 7 & 6.7 \\
\hline & KSČM (No. 2096) & 1996 & 3 & 9 & 7 & 6.3 \\
\hline \multirow{2}{*}{ 1996-1998 } & KSČM (No. 104) & 1996 & 3 & 9 & 7 & 6.3 \\
\hline & ČSSD (No. 149) & 1997 & 8 & 5 & 3 & 5.3 \\
\hline \multirow{4}{*}{ 1998-2002 } & ČSSD (No.18) & 1998 & 8 & 5 & 3 & 5.3 \\
\hline & KDU-ČSL (No. 120) & 1999 & 3 & 5 & 3 & 3.7 \\
\hline & ČSSD (No.695) & 2000 & 5 & 7 & 7 & 6.3 \\
\hline & ČSSD (No. 1039) & 2001 & 5 & 6 & 1 & 4 \\
\hline $2002-2006$ & ČSSD (No. 914) & 2005 & 4 & 6 & 1 & 3.7 \\
\hline \multirow{2}{*}{ 2006-2010 } & KSČM (No. 134) & 2007 & 2 & 6 & 1 & 3 \\
\hline & ČSSD (No. 192) & 2007 & 2 & 5 & 2 & 3 \\
\hline \multirow{3}{*}{ 2010-2013 } & ČSSD (No. 8) & 2010 & 2 & 5 & 2 & 3 \\
\hline & ČSSD (No. 520) & 2011 & 2 & 5 & 2 & 3 \\
\hline & LIDEM (No. 661) & 2012 & 3 & 1 & 5 & 3 \\
\hline
\end{tabular}




\begin{tabular}{|l|l|c|c|c|c|c|}
\hline $\begin{array}{c}\text { Parliamentary } \\
\text { term }\end{array}$ & \multicolumn{1}{|c|}{ Political party } & Year & $\mathrm{IT}_{\mathrm{SC}}$ & $\mathrm{R}_{\mathrm{SC}}$ & $\mathrm{AQ}_{\mathrm{SC}}$ & $\mathrm{AG}_{\mathrm{SC}}$ \\
\hline \multirow{3}{*}{$2013-2017$} & Úsvit (No. 114) & 2014 & 1 & 2 & 1 & 1.3 \\
\cline { 2 - 7 } & KSČM (No.116) & 2014 & 1 & 4 & 1 & 2 \\
\cline { 2 - 7 } & ČSSD (No. 559) & 2015 & 3 & 3 & 4 & 3.3 \\
\hline \multirow{3}{*}{$2017-$} & SPD (No. 35) & 2017 & 1 & 2 & 1 & 1.3 \\
\cline { 2 - 7 } & ČSSD (No. 111) & 2018 & 6 & 5 & 6 & 5.7 \\
\cline { 2 - 7 } & KSC̆M (No. 117) & & & 4 & 1 & 2 \\
\hline
\end{tabular}

Source: Author's own studies.

\section{BIBLIOGRAPHY}

Altman, D. 2017. The Potential of Direct Democracy: A Global Measure (1900-2014), "Social Indicators Research: An International and Interdisciplinary Journal for Quality-of-Life Measurement”, vol. 133 (3), DOI: http//dx.doi.org/10.1007/s11205-016-1408-0.

Amendment No. 914/2. 2005. Amendment and other proposals to the press 914/0, Joint Czech and Slovak Digital Parliamentary Library, https:/www.psp.cz/sqw/text/tiskt.sqw?O=4\&CT=914\&CT1 $=2$ (access: 28.06.2018).

Constitution of the Czech Republic 1992.

Constitutional Law No. 515/2002. 2002. On the referendum on the accession of the Czech Republic to the European Union. Joint Czech and Slovak Digital Parliamentary Library, http://www.psp.cz/sqw/ sbirka.sqw? $=4 \& \mathrm{~T}=50$ (access: 28.06 .2018 ).

Gross, A., Kaufmann, B. 2002. IRI Europe country index on citizen law making 2002: A report on design and rating of the $I \& R$ requirements and practices of 32 European states, IRI Europe, Amsterdam.

Kużelewska, E. 2014. Referendum in the Czech Republic and Slovakia, "Annales UMCS. Sectio K", vol. 21 (1).

Law proposal No. 1039. 2001. Governmental Draft of the Constitutional Law on Referendum. Joint Czech and Slovak Digital Parliamentary Library, https:/www.psp.cz/sqw/text/tiskt.sqw?O=3\&CT=1039\&CT1=0 (access: 28.06.2018).

Law proposal No. 104. 1996. Draft of the Constitutional Act on the Referendum and the Supplement to the Constitution of the Czech Republic. Joint Czech and Slovak Digital Parliamentary Library, http:// public.psp.cz/eknih/1996ps/tisky/t010400.htm (access: 28.06.2018).

Law proposal No. 111. 2018. Draft of the Law on the Nationwide Referendum. Joint Czech and Slovak Digital Parliamentary Library, https://www.psp.cz/sqw/text/tiskt.sqw?O=8\&CT=111\&CT1 $=0$ (access: 28.06.2018).

Law proposal No. 114. 2014. Draft of the Constitutional Law on the Nationwide Referendum. Joint Czech and Slovak Digital Parliamentary Library, https://www.psp.cz/sqw/text/tiskt.sqw?O=7\&CT=114\&CT1=0 (access: 28.06.2018).

Law proposal No. 116. 2014. Draft of the Constitutional Law on Referendum. Joint Czech and Slovak Digital Parliamentary Library, https:/www.psp.cz/sqw/text/tiskt.sqw?O=7\&CT=116\&CT1 $=0$ (access: 28.06.2018).

Law proposal No. 117. 2018. Draft of the Constitutional Law on Referendum. Joint Czech and Slovak Digital Parliamentary Library, https:/www.psp.cz/sqw/text/tiskt.sqw? $=8 \& C T=117 \& C T 1=0$ (access: 28.06.2018).

Law proposal No. 120. 1999. Draft of the Constitutional Law on Referendum. Joint Czech and Slovak Digital Parliamentary Library, https:/www.psp.cz/sqw/text/tiskt.sqw?O=3\&CT=120\&CT1 $=0$ (access: 28.06.2018). 
Law proposal No. 134. 2007. Draft of the Constitutional Law on the Nationwide Referendum. Joint Czech and Slovak Digital Parliamentary Library, https://www.psp.cz/sqw/text/tiskt.sqw?O=5\&CT=134\&CT1=0 (access: 28.06.2018).

Law proposal No. 149. 1997. Draft of the Constitutional Law on Referendum and Citizen Legilative Initiative. Joint Czech and Slovak Digital Parliamentary Library, http://public.psp.cz/eknih/1996ps/tisky/ t014900.htm (access: 28.06.2018).

Law proposal No. 18. 1998. Draft of the Constitutional Law on Popular Vote. Joint Czech and Slovak Digital Parliamentary Library, https://www.psp.cz/sqw/text/tiskt.sqw?O $=3 \& \mathrm{CT}=18 \& \mathrm{CT} 1=0$ (access: 28.06.2018).

Law proposal No. 1874. 1995. Draft of the Constitutional Law on Referendum. Joint Czech and Slovak Digital Parliamentary Library, http://public.psp.cz/eknih/1993ps/tisky/t187400.htm (access: 28.06.2018).

Law proposal No. 192. 2007. Draft of the Constitutional Law on the Nationwide Referendum. Joint Czech and Slovak Digital Parliamentary Library, https://www.psp.cz/sqw/text/tiskt.sqw?O=5\&CT=192\&CT1=0 (access: 28.06.2018).

Law proposal No. 2096. 1996. Constitutional Law on the Referendum and the Amendment to the Constitution. Joint Czech and Slovak Digital Parliamentary Library, http://public.psp.cz/eknih/1993ps/tisky/ t209600.htm (access: 28.06.2018).

Law proposal No. 35. 2017. Draft of the Law on the Nationwide Referendum. Joint Czech and Slovak Digital Parliamentary Library, https://www.psp.cz/sqw/text/tiskt.sqw?O $=8 \& \mathrm{CT}=35 \& \mathrm{CT} 1=0$ (access: 28.06.2018).

Law proposal No. 494. 1993. Constitutional Law on Referendum. Joint Czech and Slovak Digital Parliamentary Library, http://public.psp.cz/eknih/1993ps/tisky/t049400.htm (access: 28.06.2018).

Law proposal No. 520. 2011. Draft of the Constitutional Law on the Nationwide Referendum. Joint Czech and Slovak Digital Parliamentary Library, https://www.psp.cz/sqw/text/tiskt.sqw?O=6\&CT=520\&CT1 $=0$ (access: 28.06.2018).

Law proposal No. 559. 2015. Governmental Draft of the Constitutional Law on the Nationwide Referendum. Joint Czech and Slovak Digital Parliamentary Library, https://www.psp.cz/sqw/text/tiskt. sqw? $=7 \& C T=559 \& C T 1=0$ (access: 28.06 .2018 ).

Law proposal No. 661. 2012. Governmental Draft of the Constitutional Law on the Nationwide Referendum. Joint Czech and Slovak Digital Parliamentary Library, https://www.psp.cz/sqw/text/tiskt. sqw? $=6 \& C T=661 \& C T 1=0$ (access: 28.06 .2018 ).

Law proposal No. 695. 2000. Governmental Draft of the Law on Referendum. Joint Czech and Slovak Digital Parliamentary Library, https://www.psp.cz/sqw/text/tiskt.sqw?O $=3 \& \mathrm{CT}=695 \& \mathrm{CT} 1=0$ (access: 28.06.2018).

Law proposal No. 8. 2010. Draft of the Constitutional Law on the Nationwide Referendum. Joint Czech and Slovak Digital Parliamentary Library, https://www.psp.cz/sqw/text/tiskt.sqw?O $=6 \& C T=8 \& C T 1=0$ (access: 28.06.2018).

Law proposal No. 914. 2005. Governmental Draft of the Constitutional Law on the Nationwide Referendum. Joint Czech and Slovak Digital Parliamentary Library, https://www.psp.cz/sqw/text/tiskt. sqw? $=4 \& C T=914 \& C T 1=0$ (access: 28.06 .2018 ).

Lebeda, T. 2003. Referendum o přistoupení ČR k Evropské unii. Několik různých pohledů na prvni všelidové hlasovánív Česku, "Politologický časopis", vol. 3/2004.

Maniquet, F., Morelli, M. 2010. Approval quorums dominate participation quorums, EUI Working Papers, ECO 2010/13.

Mates, P. 2004. Komezeni místního referenda, "Právní zpravodaj", vol. 4.

Mates, P. 2007. Právní úprava místního referenda, "Právní fórum", vol. 2.

Ministry of Interior. 2018. Local referendums report table 2006-2018, www.mvcr.cz/soubor/mistni-referenda-tabulka-hlaseni.aspx (access: 28.06.2018).

Munck, G.L., Verkuilen, J. 2002. Conceptualizing and measuring democracy: Evaluating alternative indices, "Comparative Political Studies", vol. 35 (1). 
Pavlíček, V. 2002. O české státnosti. Úvahy a polemiky, Karolinum, Praha.

Pavlíček, V., Hřebejk, J. 1998. Ústava a ústavní rád České republiky. Komentářr. Díl 1. Ústavní systém. 2. dopl. a podstatně rožs., Linde, Praha.

Pechanec, P. 2011. Př́má demokracie v České republice, Wolters Kluwer ČR, Praha.

Perottino, M. 2005. The Czech Accession Referendum: 'Yes', But No Passion, [in:] European Union Accession Referendums, J.-M. De Waele (ed.), Université Libre de Bruxelles, Brussels.

Sládeček, V., Mikule, V., Syllová, J. 2007. Ústava České republiky, 1. vydání, C.H. Beck, Praha.

Šimíček, V. 2003. Právní zakotvení institutu referenda v ústavním pořádku České republiky, "Politologický časopis", vol. 2.

Špok, R., Řiháčková, V., Weiss, T., Bartovic, V., Dromard, J. 2006. Mistní referenda v České republice a ve vybraných zemich Evropské unie, Institut Europeum, Praha.

Vatter, A. 2009. Lijphart expanded: Three dimensions of democracy in advanced OECD countries?, "European Political Science Review", vol. 1 (1), DOI: https://doi.org/10.1017/S1755773909000071.

Vedral, J. 2004. Ještě k omezeni mistního referenda, "Právní zpravodaj", vol. 10.

Vojtíšková, K. 2016. Česká cesta k participativnímu rozpočtování, http://utopia.sk/liferay/home/-/asset_ publisher/c8Vy/content/katerina-vojtiskova-ceska-cesta-k-participativnimu-rozpoctovani/187913/ pop_up?_101_INSTANCE_c8Vy_viewMode=print (access: 28.06.2018).

\section{BIOGRAPHY}

Dušan Brabec, PhD student at the Institute of Political Studies, Faculty of Social Sciences, Charles University. E-mail: dusan.brabec@fsv.cuni.cz 